\title{
Behandlingen av type 1-diabetes i spesialisthelsetjenesten - data fra Norsk diabetesregister for voksne
}

BAKGRUNN Norsk diabetesregister for voksne ble opprettet i 2005. Formålet med under-
søkelsen er å vurdere kvaliteten på behandlingen av voksne pasienter med type 1-diabetes
i spesialisthelsetjenesten basert på registerdata.

MATERIALE OG METODE Vi inkluderte pasienter $\geq 18$ år med type 1-diabetes i spesialisthelsetjenesten som registeret har data for i perioden 1.7. 2010-31.12. 2011. Pasientene ble spurt om samtykke til å overføre data til registeret når de møtte til rutinekontroll. $95 \%$ av forespurte pasienter per 31.12. 2011 samtykket. Det er ikke kjent hvor stor andel som ble spurt.

RESULTATER Vi inkluderte sist registrerte data for 3697 pasienter (46,8\% kvinner) fra 24 poliklinikker og spesialistsentre. Gjennomsnittsalderen var 41,8 år og gjennomsnittlig sykdomsvarighet 20,8 år. Median HbA1c, systolisk blodtrykk og LDL-kolesterol var henholdsvis $8,0 \%, 126 \mathrm{~mm} \mathrm{Hg}$ og 2,8 mmol/l. 9,8\% nådde alle behandlingsmålene i de nasjonale retningslinjene for diabetes. $18 \%$ hadde $\mathrm{HbA} 1 \mathrm{c} \leq 7,0 \%$, mens $22 \%$ hadde $\mathrm{HbA} 1 \mathrm{c} \geq 9 \%$. $39 \%$ av pasienter på statinbehandling nådde behandlingsmålet for LDL-kolesterol. 19,6\% røykte daglig. 14,9\% hadde laserbehandlet retinopati og 5,8\% kjent koronarsykdom. Det manglet dokumentasjon på gjennomført fotunders økelse og øyebunnsunders $\emptyset$ kelse hos henholdsvis $33 \%$ og $29 \%$ av pasientene.

FORTOLKNING De foreløpige registerdataene tyder på at diabetesbehandlingen bør forbedres både mht. gjennomføring av anbefalte prosedyrer og andelen som når behandlingsmålene.

Forekomsten av diabetes er økende i Norge og i resten av verden (1). Tall fra Reseptregisteret for 2011 tilsier at det er det ca. 200000 personer med kjent diabetes i Norge (2), og av disse har ca. 25000 type 1-diabetes. God diabetesbehandling reduserer hyppigheten av makro- og mikrovaskulære senkomplikasjoner (3-5).

Helseministeren lanserte i 2006 en nasjonal diabetesstrategi for 2006-10, der nasjonale data om kvaliteten på diabetesbehandlingen ble etterlyst. I 2009 utga Helsedirektoratet nasjonale faglige retningslinjer for forebygging, diagnostikk og behandling av diabetes (6). Også i disse retningslinjene etterlyses data om kvaliteten på diabetesbehandlingen. Kvaliteten i allmennpraksis har vært belyst tidligere i noen tverrsnittsundersøkelser og omhandler i hovedsak personer med type 2-diabetes $(7,8)$. Det foreligger ingen publikasjoner fra spesialisthelsetjenesten i Norge om kvaliteten på diabetesbehandlingen hos voksne med type 1-diabetes. I forbindelse med samhandlingsreformen kan det være særlig viktig å følge med på behandlingskvaliteten av type 1-diabetes for å sikre at pasientene blir behandlet på rett nivå i helsetjenesten.

Norsk diabetesregister for voksne ble opprettet i 2005 etter anbefaling fra Helseog omsorgsdepartementet. Det er et sam- tykkebasert nasjonalt kvalitetsregister med mandat til å samle inn data fra både primærog spesialisthelsetjenesten. Helse Bergen er eier av registeret, mens den daglige driften er lagt til Norsk kvalitetsforbedring av laboratorievirksomhet utenfor sykehus (Noklus) i Bergen. De første årene ble brukt til å definere registervariabler og til utvikling av et elektronisk registreringsverktøy (Noklus Diabetes), som samtidig fungerer som en diabetesjournal. Dette er i tråd med oppdragsdokumentet til helseforetakene, som pålegger dem å ta i bruk elektroniske diabetesjournaler med tanke på en kontinuerlig kvalitetssikring av diabetesbehandlingen.

Antall sykehuspoliklinikker og spesialistklinikker som rapporterer data til Norsk diabetesregister for voksne har økt fra tre i 2009 til 24 i 2011. Deltakerne får en årlig tilbakemelding der egne data sammenstilles med data fra andre sykehus.

Formålet med denne undersøkelsen er å vurdere kvaliteten på behandlingen av pasienter $\geq 18$ år med type 1-diabetes som følges opp i spesialisthelsetjenesten basert på registerdata hovedsakelig fra 2011.

\section{Materiale og metode}

Vi inkluderte pasienter over 18 år med type 1-diabetes fulgt opp i spesialisthelsetjenesten som det var registrert data for i perioden

\author{
John G. Cooper \\ joco@sus.no \\ Noklus \\ Bergen \\ og \\ Medisinsk divisjon \\ Stavanger universitetssjukehus \\ Tor Claudi \\ Medisinsk klinikk \\ Nordlandssykehuset

\section{Hrafnkell B. Thordarson} \\ Endokrinologisk seksjon \\ Medisinsk klinikk \\ Haukeland universitetssykehus

\section{Karianne Fjeld Løvaas} \\ Noklus \\ Bergen \\ Siri Carlsen \\ Noklus \\ Bergen \\ og \\ Medisinsk divisjon
}

Stavanger universitetssjukehus

Sverre Sandberg

Geir Thue

Noklus

Bergen

Engelsk oversettelse på www.tidsskriftet.no

> Se også side 2224

\section{HOVEDBUDSKAP}

Foreløpige data fra Norsk diabetesregister for voksne viser at $22 \%$ av de registrerte pasientene med type 1-diabetes hadde dårlig glykemisk kontroll, med $\mathrm{HbA} 1 \mathrm{c} \geq 9,0 \%$

Bare $10 \%$ av pasientene nådde behandlingsmålene for HbA1c, LDL-kolesterol og blodtrykk

$20 \%$ av pasientene med type 1 -diabetes var registrert som dagligrøykere

Oppfølgingen av pasientene var ikke tilfredsstillende, særlig for fotundersøkelse og øyestatus 
Tabell 1 Oversikt over diabetespoliklinikker som rapporterer til diabetesregisteret per 31.12. $2011 \mathrm{og}$ antall pasienter fra de ulike poliklinikkene som er inkludert i denne studien

\begin{tabular}{|c|c|}
\hline Diabetespoliklinikk & $\begin{array}{c}\text { Antall } \\
\text { pasienter }\end{array}$ \\
\hline Stavanger universitetssjukehus & 796 \\
\hline Norsk Diabetikersenter & 698 \\
\hline Haukeland universitetssjukehus & 601 \\
\hline Sykehuset Østfold, Fredrikstad & 399 \\
\hline Sørlandet sykehus, Arendal & 293 \\
\hline Nordlandssykehuset Bodø & 289 \\
\hline $\begin{array}{l}\text { Universitetssykehuset } \\
\text { Nord-Norge, Troms } \varnothing\end{array}$ & 159 \\
\hline Sørlandet sykehus, Kristiansand & 105 \\
\hline Helgelandssykehuset, Mo i Rana & 72 \\
\hline $\begin{array}{l}\text { Sykehuset Innlandet, } \\
\text { Lillehammer }\end{array}$ & 47 \\
\hline Helgelandssykehuset, Mosjøen & 42 \\
\hline $\begin{array}{l}\text { Nordlandssykehuset, } \\
\text { Stokmarknes }\end{array}$ & 40 \\
\hline Haugesund sjukehus & 28 \\
\hline Hammerfest sykehus & 19 \\
\hline Nordlandssykehuset, Lofoten & 18 \\
\hline Sykehuset Innlandet, Gjøvik & 17 \\
\hline Sykehuset Innlandet, Hamar & 17 \\
\hline $\begin{array}{l}\text { Oslo universitetssykehus, } \\
\text { Ullevål' }\end{array}$ & 14 \\
\hline Stord sjukehus & 13 \\
\hline $\begin{array}{l}\text { Universitetssykehuset } \\
\text { Nord-Norge, Narvik }\end{array}$ & 11 \\
\hline Diverse $^{2}$ & 19 \\
\hline Totalt & 3697 \\
\hline \multicolumn{2}{|c|}{$\begin{array}{l}{ }^{1} \text { Alle har rapportert inn data via Noklus Diabetes } \\
\text { med unntak av Ullevål som har rapportert via } \\
\text { Medisinsk Registreringssystem }\end{array}$} \\
\hline $\begin{array}{l}2 \text { Diakonhjemmet Sykehus i Oslo, Diab } \\
\text { i Trondheim, Helgelandssykehuset is } \\
\text { og Haraldsplass Diakonale Sykehus }\end{array}$ & $\begin{array}{l}\text { tesklinikken } \\
\text { andnessjøen } \\
\text { Bergen }\end{array}$ \\
\hline
\end{tabular}

1.7. 2010-31.12. 2011. Siste registrering for de ulike variablene ble benyttet. For enkelte variabler, som øyebunnsundersøkelse, vil denne registreringen kunne være før 1.7. 2010. Vi har imidlertid ikke tatt med pasienter uten noen registreringer i perioden 1.7. 2010-31.12. 2011. Dataene ble utlevert i avidentifisert form.

Behandlende leges diagnose er lagt til grunn for klassifiseringen. Pasientene ble
Tabell 2 Alders- og kiønnsfordeling for pasienter med type 1-diabetes i spesialisthelsetjenesten som det var registrert data for i perioden 1.7. 2010-31.12. 2011

\begin{tabular}{lrcc}
\hline Alder, år & Antall & $(\%)$ & $\begin{array}{c}\text { Andel } \\
\text { kvinner } \\
(\%)\end{array}$ \\
$18-19$ & 124 & $(3,4)$ & 46,8 \\
$20-29$ & 767 & $(20,7)$ & 47,1 \\
$30-39$ & 803 & $(21,7)$ & 50,3 \\
$40-49$ & 918 & $(24,8)$ & 45,5 \\
$50-59$ & 596 & $(16,1)$ & 44,1 \\
$60-69$ & 353 & $(9,5)$ & 47,3 \\
$70-80$ & 120 & $(3,2)$ & 52,5 \\
$\geq 81$ & 16 & $(0,4)$ & 62,5 \\
Totalt & 3697 & $(100)$ & 47,2 \\
\hline
\end{tabular}

Tabell 3 Registrerte prosedyrer ved behandling av pasienter $\geq 18$ år med type 1 diabetes for sykehus som hadde brukt diabetesjournalen Noklus Diabetes siden 2009 $\mathrm{N}=1378$ pasienter dersom ikke annet er oppgitt

Prosedyre registrert ${ }^{1}$ (\%)

\begin{tabular}{ll} 
Høyde angitt & 96 \\
Måling av HbA1c & 94 \\
Måling av LDL-kolesterol & 92 \\
$\begin{array}{l}\text { Kartlegging om det er tidlig } \\
\text { koronarsykdom i familien }\end{array}$ & 92 \\
$\begin{array}{l}\text { Vekt angitt } \\
\text { Måling av blodtrykk }\end{array}$ & 82 \\
$\begin{array}{l}\text { Måling av mikroalbumin } \\
\text { Røykevaner angitt }\end{array}$ & 81 \\
$\begin{array}{l}\text { Undersøkelse av øyebunn (dia- } \\
\text { betesvarighet } \geq 5 \text { år) (n = 1 206) }\end{array}$ & 71 \\
$\begin{array}{l}\text { Undersøkelse med monofila- } \\
\text { ment og/eller stemmegaffel } \\
\text { (diabetesvarighet } \geq 5 \text { år) } \\
\text { (n = } 1 \text { 206) }\end{array}$ & 73 \\
$\begin{array}{l}\text { Unders } ø \text { kelse av fotpuls (dia- } \\
\text { betesvarighet } \geq 5 \text { år) (n = 1 206) }\end{array}$ & 66 \\
\hline
\end{tabular}

1 For HbA1c, blodtrykk, røykevaner, mikroalbumin, vekt og undersøkelse av føtter er kun data fra 1.10. 2010-31.12. 2011 tatt med (15 måneder tilbake). Måling av kolesterol/LDL og undersøkelse av øyebunn er tatt med dersom det foreligger svar fra 1.7.2009-31.12.2011 (30 måneder tilbake). Høyde og tidlig koronarsykdom i familien er tatt med uansett dato spurt fortløpende om data kunne sendes til registeret når de møtte til vanlig kontrolltime. $95 \%$ av forespurte pasienter per 31.12. 2011 samtykket. Vi kjenner ikke andelen forespurte pasienter av dem som kom til kontrolltime. Flere av sykehusene var i en tidlig fase med å levere data til Diabetesregisteret og har derfor registrert data for en relativt liten del av sin pasientpopulasjon. Registervariablene omfatter diabetesvarighet, gjennomføring av ulike prosedyrer, risikofaktorer, behandling og diabetesrelaterte komplikasjoner. Fullstendig oversikt over variablene finnes på Noklus' internettside (9).

Behandlingsmål og utvalgte prosedyrer som ble brukt som kvalitetsmål i denne undersøkelsen, er basert på anbefalingene i nasjonale faglige retningslinjer fra 2009 (6), dvs. måloppnåelse for $\mathrm{HbA1c}(\leq 7 \%)$, for blodtrykk (systolisk $\leq 135 \mathrm{~mm} \mathrm{Hg}$, diastolisk $\leq 80 \mathrm{~mm} \mathrm{Hg}$ ) og for lipider (LDL-kolesterol $\leq 2,5 \mathrm{mmol} / 1$ uten kjent hjerte- og karsykdom, $\leq 1,8 \mathrm{mmol} / 1$ ved kjent hjerte- og karsykdom) samt gjennomføring av prosedyrer for å avdekke risikofaktorer og tidlige komplikasjoner. Retningslinjene anbefaler at de fleste prosedyrer utføres årlig, men noen anbefales utført annethvert år (6). Det er ikke alltid mulig å gjennomføre kontrollene med nøyaktig ett eller to års mellomrom, og vi har derfor utvidet tidsperioden for utførte prosedyrer til hhv. 15 og 30 måneder.

Programvaren Noklus Diabetes, som de fleste som leverer data bruker, er både et klinisk verktøy med beslutningsstøtte og et innsamlingsverktøy for registeret og utgjør en nærmest komplett diabetesjournal. Registreringen gjøres av lege og/eller sykepleier i forbindelse med konsultasjonen. Programmet kommuniserer med poliklinikkens journalsystem, slik at data registrert i journalen enkelt eksporteres til hovedjournalen, mens andre data (personalia og laboratoriedata) importeres fra hovedjournalen til diabetesjournalen. Registeret inneholder derfor også opplysninger om enkelte undersøkelser som ble gjort før pasienten ble inkludert. I tillegg har man utviklet Medisinsk Registreringssystem (MRS), som kan benyttes til manuell inntasting av registervariablene via Norsk Helsenett. Dette er en løsning for sykehus som foreløpig ikke kan eller ikke ønsker å ta Noklus Diabetes i bruk.

Alle helseregioner leverte krypterte elektroniske data via Noklus Diabetes, med unntak av Oslo universitetssykehus, Ullevål som brukte Medisinsk Registreringssystem. Deskriptiv statistikk ble utført i statistikkprogrammet SPSS versjon 20. Vi beregnet konfidensintervaller basert på binomisk fordeling for prosentandel kvinner og menn registrert med hver komplikasjon. Undersøkelsen ble vurdert av regional etisk komité og funnet ikke fremleggingspliktig. 


\section{Resultater}

Resultatene er basert på pasientdata fra 22 sykehuspoliklinikker og to spesialistsentre, til sammen 3697 pasienter (tab 1). Tabell 2 viser alders- og kjønnsfordeling i de forskjellige aldersgruppene. Gjennomsnittsalderen var 41,8 år og gjennomsnittlig sykdomsvarighet 20,8 år. 3,6\% var over 70 år. Gjennomsnittlig kroppsmasseindeks (BMI) for menn og kvinner var henholdsvis $26,3 \mathrm{~kg} / \mathrm{m}^{2}$ og $25,9 \mathrm{~kg} / \mathrm{m}^{2} .19,6 \%$ av pasientene var registrert som dagligrøykere, og andelen var omtrent lik blant kvinner og menn og blant pasienter over og under 40 år.

Tabell 3 viser registrerte prosedyrer ved de sykehusene som har hatt Noklus Diabetes i bruk siden første kvartil 2009, dvs. tilstrekkelig lenge til å gjøre prosedyrer som bare er anbefalt annethvert år. Prosentandelen registrerte prosedyrer var $66-96 \%$.

Tabell 4 viser andelen som fikk medikamentell behandling med insulinpumpe, antihypertensiver, statiner, acetylsalisylsyre eller warfarin i 2011. Andelen som fikk behandling med antihypertensiver, statiner og acetylsalisylsyre var høyest $\mathrm{i}$ aldersgruppen $\geq 40$ år.

Tabell 5 viser fordelingen av verdier for HbA1c, blodtrykk og lipider, og tabell 6 prosentandelen som nådde behandlingsmålene. $18 \%$ av pasientene nådde behandlingsmålet på $\mathrm{HbA} 1 \mathrm{c} \leq 7 \%$, mens $22 \%$ hadde $\mathrm{HbA} 1 \mathrm{c}$ $\geq 9 \%$. Median HbAlc var omkring 8,0\% i de fleste aldersgrupper hos begge kjønn og $8,4 \%$ hos de yngste (18-24 år). Pasienter med insulinpumpe hadde median $\mathrm{HbA} 1 \mathrm{c}$ på $8,3 \%$ og pasienter med annen insulinbehandling $\mathrm{HbA} 1 \mathrm{c}$ på $8,0 \%$. HbA1c-verdier var median $7,2 \%$ ved $>63$ blodglukosemålinger/uke $(\mathrm{n}=80), 7,7 \%$ ved 29-63 målinger/uke $(n=626), 8,1 \%$ ved 15-28 målinger/uke $(n=492)$ og $8,4 \%$ ved $1-14$ målinger/uke $(n=410)$.

Median systolisk og diastolisk blodtrykk hos menn var 130/80 mm Hg, mens kvinner hadde medianverdier på 122/78 $\mathrm{mm} \mathrm{Hg}$. $57 \%$ av pasienter på antihypertensiver nådde behandlingsmålet på systolisk blodtrykk $\leq 135 \mathrm{~mm} \mathrm{Hg}$. For pasienter på statinbehandling nådde $39 \%$ behandlingsmålet for LDL-kolesterol: $42 \%$ av dem uten kjent hjerte- og karsykdom og $33 \%$ av dem med kjent hjerte- og karsykdom. Vi hadde ikke informasjon om statindosen hos pasienter som ikke nådde behandlingsmålet. $9,8 \%$ av pasientene nådde samtlige av behandlingsmålene for $\mathrm{HbAlc}$, systolisk blodtrykk og LDL-kolesterol.

Tabell 7 gir oversikt over komplikasjonsfrekvens. Median diabetesvarighet hos pasienter med komplikasjoner var omkring 30 år uansett type komplikasjon. Perifer nevropati var registrert hos 13,8\% (95\% KI $11,3-16,3)$ av menn og hos $7,2 \%(95 \% \mathrm{KI}$
Tabell 4 Andel av registrerte pasienter $\geq 18$ år med type 1-diabetes som i 2011 ble behandlet med insulinpumpe, antihypertensiver, statiner, acetylsalisylsyre og warfarin. Andelene er beregnet ut fra antall pasienter med data om medikamentbruk, som varierte fra laveste 2508 (warfarin) til høyeste 2944 (insulinpumpe) for de ulike medikamentene

\begin{tabular}{|c|c|c|c|}
\hline $\begin{array}{l}\text { Behandling } \\
\text { (data foreligger) }\end{array}$ & $\%$ & $\begin{aligned} & \% \\
< & 40 \mathrm{ar}\end{aligned}$ & $\begin{aligned} & \% \\
\geq & 40 \stackrel{\circ}{ }\end{aligned}$ \\
\hline $\begin{array}{l}\text { Insulinpumpe } \\
(\mathrm{n}=2944)^{1}\end{array}$ & 30,0 & 32,3 & 28,0 \\
\hline $\begin{array}{l}\text { Antihypertensiver } \\
(n=2530)\end{array}$ & 28,6 & 10,1 & 41,7 \\
\hline Statiner $(n=2531)$ & 26,7 & 6,7 & 42,6 \\
\hline $\begin{array}{l}\text { Acetylsalisylsyre } \\
(n=2524)\end{array}$ & 14,2 & 1,6 & 24,5 \\
\hline Warfarin ( $n=2508$ ) & 1,8 & 0,4 & 2,8 \\
\hline
\end{tabular}

1 Pasienter som ikke bruker insulinpumpe, får annen insulinbehandling

Tabell 5 Fordelingen av verdier for $\mathrm{HbA1}$, blodtrykk og lipider hos pasienter $\geq 18$ år med type 1-diabetes fulgt opp i spesialisthelsetjenesten og med data registrert i Diabetesregisteret i perioden 1.7. 2010-31.12. 2011

\begin{tabular}{|c|c|c|}
\hline $\begin{array}{l}\text { Risikofaktorer } \\
\text { (data foreligger) }\end{array}$ & $(10-9$ & $\begin{array}{l}\text { Median } \\
\text { prosentilerl }\end{array}$ \\
\hline $\mathrm{HbA} 1 \mathrm{c}(\mathrm{n}=3$ 573) & 8,0 & $(6,7-9,7)$ \\
\hline $\begin{array}{l}\text { Systolisk blodtrykk } \\
\text { ( }=2829)\end{array}$ & 126 & $(110-149)$ \\
\hline $\begin{array}{l}\text { Systolisk blodtrykk } \\
\mathrm{m} / \text { beh }(\mathrm{n}=544)^{*}\end{array}$ & 134 & $(115-160)$ \\
\hline $\begin{array}{l}\text { Systolisk blodtrykk } \\
\text { u/behandling } \\
(n=1446)^{1}\end{array}$ & 124 & $(110-142)$ \\
\hline $\begin{array}{l}\text { Diastolisk blodtrykk } \\
\text { (n=2829) }\end{array}$ & 78 & $(65-90)$ \\
\hline $\begin{array}{l}\text { LDL-kolesterol } \\
\text { (n= } 3 \text { 422) }\end{array}$ & 2,8 & $(1,8-3,9)$ \\
\hline
\end{tabular}

Det foreligger data om eventuell medikamentell behandling av hypertensjon hos 1990 av 2829 pasienter der blodtrykk er registrert

5,2-9,2) av kvinner, sår hos 5,4\% (95\% KI $4,3-6,5)$ av menn og 2,3\% (95\% KI 1,5-3,1) av kvinner og amputasjoner hos $1,3 \%(95 \% \mathrm{KI} 0,7-1,9)$ av menn og $0,2 \%$ (95\% KI 0-0,4) av kvinner. Mikroalbuminuri eller proteinuri ble funnet hos $9 \%$ med estimert glomerulær filtrasjonshastighet $(\mathrm{eGFR}) \geq 60 \mathrm{ml} / \mathrm{min} / 1,73 \mathrm{~m}^{2}$ og hos $18,3 \%$ med eGFR $<60 \mathrm{ml} / \mathrm{min} / 1,73 \mathrm{~m}^{2}$.
Tabell 6 Prosentandel som nådde behandlingsmålene for $\mathrm{HbA1c}$, blodtrykk og LDLkolesterol blant pasienter $\geq 18$ år med type 1-diabetes fulgt opp i spesialisthelsetjenesten og med data registrert i Diabetesregisteret i perioden 1.7. 2010-31.12. 2011

\begin{tabular}{|c|c|}
\hline Behandlingsmål (data foreligger) & $\begin{array}{c}\text { Andel } \\
(\%)\end{array}$ \\
\hline $\mathrm{HbA} 1 \mathrm{c} \leq 7(\mathrm{n}=3573)$ & 18 \\
\hline $\begin{array}{l}\text { Systolisk blodtrykk } \leq 135 \\
\text { ( } n=2 \text { 829) }\end{array}$ & 74 \\
\hline $\begin{array}{l}\text { Systolisk blodtrykk } \leq 135 \\
\text { u/behandling }(n=1446)^{1}\end{array}$ & 81 \\
\hline $\mathrm{SBT} \leq 135 \mathrm{~m} /$ beh $(\mathrm{n}=544)^{1}$ & 57 \\
\hline $\begin{array}{l}\text { Diastolisk blodtrykk } \leq 80 \\
\text { ( } n=2 \text { 829) }\end{array}$ & 73 \\
\hline $\begin{array}{l}\text { LDL-kolesterol } \leq 3,5 \text { (uten kjent } \\
\text { hjerte- og karsykdom og ikke } \\
\text { statinbehandlet, } n=1285)^{2}\end{array}$ & 79 \\
\hline $\begin{array}{l}\text { LDL-kolesterol } \leq 2,5 \text { luten kjent } \\
\text { hjerte- og karsykdom og statin- } \\
\text { behandlet, } n=403)^{2}\end{array}$ & 42 \\
\hline $\begin{array}{l}\text { LDL-kolesterol } \leq 1,8 \text { (med kjent } \\
\text { hjerte- og karsykdom, } n=224)^{2}\end{array}$ & 33 \\
\hline \multicolumn{2}{|c|}{$\begin{array}{l}{ }^{1} \text { Det foreligger data om eventuell medikamentell } \\
\text { behandling av hypertensjon hos } 1990 \text { av } 2829 \\
\text { pasienter der blodtrykk er registrert }\end{array}$} \\
\hline $\begin{array}{l}2 \text { Det foreligger data om ev. hjerte- og } \\
\text { hos } 1912 \text { av } 3422 \text { pasienter der LDL- } \\
\text { er målt }\end{array}$ & $\begin{array}{l}\text { sykdom } \\
\text { esterol }\end{array}$ \\
\hline
\end{tabular}

\section{Diskusjon}

Aldersfordeling

Basert på data i Diabetesregisteret er pasienter med type 1-diabetes en relativt ung pasientgruppe, der $2 / 3$ er under 50 år og bare $4 \%$ er 70 år eller eldre, mot $10 \%$ i befolkningen som helhet (10). Flere faktorer kan bidra til det lave antallet pasienter $\geq 70$ år: Flere eldre pasienter følges trolig opp av sin fastlege og er ikke med i denne undersøkelsen. Forklaringen støttes av at i de skotske og svenske diabetesregistrene $(11,12)$, med betydelig rapportering også fra allmennleger, er ca. $7 \%$ av pasienter med type 1-diabetes 70 år eller eldre. Forekomsten av type 1-diabetes har $ø \mathrm{kt}$ de siste desenniene og fører til at en forholdsvis stor andel av pasientene med type 1-diabetes fortsatt er unge. Det er også sannsynlig at pasienter med type 1-diabetes har redusert levetid. Type 1-diabetespasienter under 15 år ved diagnosetidspunkt og født 1973-83 i Norge hadde fire ganger høyere dødelighet enn i normalbefolkningen (13). I en nylig publisert studie fra USA var forventet levetid 15 år kortere for diabetespasienter diagnostisert i perioden 1950-64 sammenliknet med pasienter diagnostisert i perioden 1965-80 (14). En studie fra Skottland i perioden 
Tabell 7 Antall og prosentandelen fordelt etter kjønn av pasienter $\geq 18$ år med type 1-diabetes fulgt opp i spesialisthelsetjenesten som har registrerte komplikasjoner i 2011

\begin{tabular}{|c|c|c|c|c|}
\hline Komplikasjon (data foreligger) & $\begin{array}{l}\text { Antall } \\
\text { registrerte } \\
\text { komplika- } \\
\text { sjoner totalt }\end{array}$ & $\begin{array}{c}\% \\
\text { hos kvinner }\end{array}$ & $\begin{array}{c}\% \\
\text { hos menn }\end{array}$ & $\begin{array}{c}\% \\
\text { hos alle }\end{array}$ \\
\hline Koronarsykdom ( $\mathrm{n}=2$ 789) & 162 & 4,6 & 6,8 & 5,8 \\
\hline Hjerneslag ( $n=2$ 789) & 36 & 1,0 & 1,5 & 1,3 \\
\hline Amputasjon ( $n=2$ 789) & 23 & 0,2 & 1,3 & 0,8 \\
\hline Karkirurgi ( $n=2789$ ) & 33 & 0,6 & 1,7 & 1,2 \\
\hline Hatt sår nedenfor ankelen ( $n=2$ 789) & 111 & 2,3 & 5,4 & 4,0 \\
\hline Ikke laserbehandlet retinopati ( $n=2789$ ) & 394 & 13,2 & 14,9 & 14,1 \\
\hline Laserbehandlet retinopati ( $\mathrm{n}=2$ 789) & 415 & 14,3 & 15,3 & 14,9 \\
\hline Mikroalbuminuri (n = 2 789) & 195 & 5,6 & 8,1 & 7,0 \\
\hline Proteinuri ( $n=2789$ ) & 53 & 1,4 & 2,3 & 1,9 \\
\hline Manglende fotpuls ( $n=1341$ ) & 53 & 3,2 & 4,6 & 4,0 \\
\hline Perifer nevropati ( $n=1382$ ) & 148 & 7,2 & 13,8 & 10,7 \\
\hline \multicolumn{5}{|l|}{ eGFR ( $n=3594):$} \\
\hline$<15$ & 3 & 0,1 & 0,1 & 0,1 \\
\hline $15-29$ & 25 & 0,5 & 0,9 & 0,7 \\
\hline $30-44$ & 54 & 1,5 & 1,5 & 1,5 \\
\hline $45-59$ & 95 & 3,4 & 1,9 & 2,6 \\
\hline$\geq 60$ & 3417 & 94,5 & 95,6 & 95,0 \\
\hline $\begin{array}{l}\text { Minst én episode med alvorlig hypo- } \\
\text { glykemi siste året ( } n=1812 \text { ) }\end{array}$ & 299 & 18,2 & 15,1 & 16,5 \\
\hline $\begin{array}{l}\text { Noen gang innlagt for ketoacidose } \\
(n=1700)\end{array}$ & 307 & 21,7 & 15,1 & 18,0 \\
\hline
\end{tabular}

2005-07 har vist mer enn dobbel så høy mortalitet hos pasienter med type 1-diabetes sammenliknet med normalbefolkningen (15).

\section{Utførte prosedyrer}

Det er bekymringsfullt at anbefalte øyebunnsundersøkelse (6) kun er dokumentert hos $71 \%$ av pasientene på de sykehusene som har brukt diabetesjournalen siden 2009. Om dette beror på at pasientene faktisk ikke er undersøkt av øyelege eller om det er sviktende kommunikasjon mellom øyeleger og leger ved diabetespoliklinikkene, er usikkert. Til sammenlikning hadde $86 \%$ av pasienter med type 1-diabetes i Skottland (siste 15 måneder) og $96 \%$ i Sverige (siste to år) hatt øyelegeundersøkelse $(11,12)$. De nasjonale diabetesretningslinjene anbefaler årlige fotkontroller hos alle med diabetes. Vi finner at føttene er undersøkt etter gjeldende anbefalinger hos bare $2 / 3$ av pasientene, noe som er bedre enn i Sverige (58\%), men dårligere enn i Skottland $(93 \%)(11,12)$. Det er også sviktende gjennomføring av enklere rutiner, inklusive måling av HbA1c og blodtrykk (tab 3). Ved journalgjennomgang på ett av sykehusene ble det funnet at hovedårsaken til at HbAlc manglet i datasettet, var at pasienten var falt ut av kontrollrutinene på grunn av manglende legeressurser (upubliserte data, Stavanger universitetssjukehus).

\section{Behandling av risikofaktorer}

og måloppnåelse

På bakgrunn av DCCT-studien (The Diabetes Control and Complications Trial) og andre studier $(3,16-18)$ har man satt som mål at pasienter med type 1-diabetes skal ha et tilnærmet normalt blodsukker. Dette kan være vanskelig å oppnå fordi intensivert insulinbehandling kan gi uakseptabelt høy risiko for hypoglykemi. Det er imidlertid en utfordring at $22 \%$ av pasientene har dårlig glykemisk kontroll med HbAlc $\geq 9 \%$, mens kun $18 \%$ har god kontroll med HbAlc $\leq 7 \%$.

Prosentandelen av pasientene som når behandlingsmålet er lik det man oppnår $\mathrm{i}$ Sverige, der $15,2 \%$ hadde $\mathrm{HbA} 1 \mathrm{c}<6,9 \%$ i 2011, og bedre enn i Skottland, der bare $22 \%$ hadde $\mathrm{HbA} 1 \mathrm{c}<7,5 \%$ og $37,3 \%$ hadde HbAlc $>9 \%$ samme år $(11-12)$.

Type 1-diabetes er assosiert med betydelig økt risiko for kardiovaskulær sykdom (19, 20, 21), men det er uavklart om hyperglykemi per se også bidrar til dette. I Skottland ble det funnet at risikoen for kardiovaskulær sykdom var 3,0 og 2,3 ganger større hos henholdsvis kvinner og menn med type 1-diabetes sammenliknet med normalbefolkningen (15).

Det er også bekymringsfullt at så få når behandlingsmålene for lipider. $19,6 \%$ av pasientene med type 1-diabetes var registrert som dagligrøykere i 2011 sammenliknet med 17\% (i alderen 16-74 år) i den generelle befolkningen (10). I Skottland og Sverige røykte henholdsvis $25 \%$ og $12 \%$ av pasientene med type 1-diabetes i 2011 (11, 12). Dette indikerer at man må ha større fokus på røykeslutt og behandlingsmålene for $\mathrm{HbA} 1 \mathrm{c}$ og lipider hos pasienter med type 1-diabetes.

\section{Komplikasjoner}

Totalt sett er forekomsten av ikke-laserbehandlet og laserbehandlet retinopati lik, noe som trolig indikerer underrapportering av ikke-laserbehandlet retinopati, muligens på grunn av sviktende kommunikasjon mellom øyeleger og diabetespoliklinikker. Det er viktig å forbedre kartlegging av øyebunnsforandringer, siden retinopati også er assosiert med fire ganger økt mortalitet (22). Til sammenlikning er ikke-laserbehandlet retinopati hyppigere rapportert i Skottland (12). Alvorlig nyresvikt er nok noe underestimert, fordi slike pasienter ofte kontrolleres hos nefrologer. Diabetesregisteret bør arbeide for å få med også disse pasientene for å ha oversikt over antall og forløp av nyrekomplikasjoner.

\section{Begrensninger}

Pasientgrunnlaget utgjør ca. $15 \%$ av de antatt 25000 som har type 1-diabetes i Norge, og i tillegg er ikke alle datasettene fullstendige. Vi har ikke nøyaktige tall for hvor mange pasienter som sokner til hver poliklinikk og hvor mange av dem som har 
vært til kontroll som er forespurt om inklusjon i registeret, og kan derfor ikke beregne prosentandelen inkluderte pasienter. Flere poliklinikker er i en tidlig fase med å levere data til registeret og har derfor registrert data for en relativt liten del av sin populasjon, slik at vi ikke kan utelukke en viss seleksjon av pasienter i vårt materiale. Til tross for disse begrensningene tror vi at dataene er representative, siden pasientene så langt som mulig registreres fortløpende når de kommer til rutinekontroll og $95 \%$ av pasientene har samtykket til at data sendes til registeret.

Bruken av en standardisert diabetesjournal og automatisk innhenting av laboratoriedata indikerer at dataene er valide, men vi har ikke gjort systematiske studier som bekrefter at dataene overføres korrekt til Diabetesregisteret. Den eneste laboratorieprøven der benevnelsen foreløpig ikke er standardisert, er albumin i urin, noe som kan medføre litt for lav registrering av denne prosedyren (tab 3 ).

Andelen pasienter der det er gjort registrering av komplikasjoner, er gjennomgående høy, med unntak av undersøkelse for fotpuls og nevropati samt informasjon om hypoglykemi og ketoacidose. Med unntak av retinopati er vår rapportering av komplikasjoner ikke ulik Skottlands (i parentes) (12): Koronarsykdom $5,8 \% \quad(6,4 \%)$; fotsår $4,0 \%$ (4,3\%), hjerneslag 1,3\% (2,1\%), amputasjon $0,8 \%(0,6 \%)$ og retinopati $29,0 \%(51,2 \%)$. Dette tyder også på at våre data er representative og valide. Det er ikke publisert sammenliknbare komplikasjonsdata fra det svenske diabetesregisteret i 2011.

\section{Konklusjon}

Innsamling av data til Norsk diabetesregister for voksne er kommet godt i gang. Det foreligger data om kvaliteten av diabetesbehandlingen, og deltakende poliklinikker kan for første gang sammenlikne egne data med data fra andre. Dette gir gode muligheter for kvalitetsforbedrende tiltak lokalt. Diabetesregisteret mangler imidlertid data fra deler av landet, og sammenlikningsgrunnlaget vil bli bedre når også Østlandet og Midt-Norge bidrar med data.

De foreløpige resultatene viser at det er rom for forbedringer spesielt mht. behandlingen av hyperglykemi og dyslipidemi, og bare $10 \%$ av pasientene når samtlige av behandlingsmålene for HbA1c, LDL-kolesterol og blodtrykk. Pasientene må motiveres til røykeslutt, og anbefalte prosedyrer må utføres i større grad. Vi tror at bruk av en dedikert diabetesjournal som legger til rette for systematisk oppfølging og regelmessig rapportering til Diabetesregisteret vil være viktig for å møte disse utfordringene.

\section{John G. Cooper (f. 1950)}

er spesialist i endokrinologi, medisinsk ansvarlig for Norsk diabetesregister for voksne og seksjonsoverlege på endokrinologisk seksjon. Forfatter har fylt ut ICMJE-skjemaet og oppgir ingen interessekonflikter.

\section{Tor Claudi (f. 1947)}

er spesialist $i$ indremedisin og overlege ved medisinsk klinikk.

Forfatter har fylt ut ICMJE-skjemaet og oppgir ingen interessekonflikter.

\section{Hrafnkell B. Thordarson (f. 1952)}

er spesialist i endokrinologi og seksjonsoverlege på endokrinologisk seksjon.

Forfatter har fylt ut ICMJE-skjemaet og oppgir ingen interessekonflikter.

\section{Karianne Fjeld Løvaas (f. 1976)}

er bioingeniør og seksjonsleder for Norsk diabetesregister for voksne.

Forfatter har fylt ut ICMJE-skjemaet og oppgir ingen interessekonflikter.

\section{Siri Carlsen (f. 1971)}

er spesialist i endokrinologi, overlege på endokrinologisk poliklinikk og ph.d.-stipendiat ved Noklus.

Forfatter har fylt ut ICMJE-skjemaet og oppgir ingen interessekonflikter.

\section{Sverre Sandberg (f. 1950)}

er leder av Noklus, leder av Nasjonalt kompetansesenter for porfyrisykdommer (Napos) ved Haukeland universitetssykehus og professor ved Universitetet i Bergen.

Forfatter har fylt ut ICMJE-skjemaet og oppgir ingen interessekonflikter.

\section{Geir Thue (f. 1953)}

er fastlege i Bergen, seksjonsleder i Noklus og professor II ved Universitetet i Bergen. Forfatter har fylt ut ICMJE-skjemaet og oppgir ingen interessekonflikter.

\section{Litteratur}

1. Wild S, Roglic G, Green A et al. Global prevalence of diabetes: estimates for the year 2000 and projections for 2030. Diabetes Care 2004: 27 1047-53

2. Nasjonalt folkehelseinstitutt. www.reseptregisteret.no (27.5.2013)

3. The Diabetes Control and Complications Trial Research Group. The effect of intensive treatment of diabetes on the development and progression of long-term complications in insulin-dependent diabetes mellitus. N Engl J Med 1993; 329: 977-86.

4. Kearney PM, Blackwell L, Collins R et al. Efficacy of cholesterol-lowering therapy in 18,686 people with diabetes in 14 randomised trials of statins: a meta-analysis. Lancet 2008; 371: 117-25.

5. Nathan DM, Cleary PA, Backlund JY et al. Intensive diabetes treatment and cardiovascular disease in patients with type 1 diabetes. N Engl J Med 2005; 353: $2643-53$
6. Nasjonale faglige retningslinjer. Diabetes - forebygging, diagnostikk og behandling. Oslo: Helsedirektoratet, 2009.

7. Claudi T, Cooper J, Skogøy K et al. Diabetesomsorg i norsk allmennpraksis. En tilstandsrapport fra Salten og deler av Rogaland. Tidsskr Nor Lægeforen 1997: 117: 3661-4.

8. Cooper JG, Claudi T, Jenum AK et al. Quality of care for patients with type 2 diabetes in primary care in Norway is improving: results of cross-sec tional surveys of 33 general practices in 1995 and 2005. Diabetes Care 2009: 32: $81-3$.

9. Emetra. Fast trak. http://meta.emetra.no/ CRFShowForm.asp?Formld=258 (27.5.2013).

10. Statistisk sentralbyrå. www.ssb.no/a/aarbok/tab/ tab-060.html (27.5.2013)

11. Nationella diabetesregistret. Årsrapport 2011 års resultat. www.kvalitetsregister.se/ BinaryLoader.axd?OwnerID=7c46f37f-9349-4944bff3-965e1a499b0a\&OwnerType=0\&PropertyName =Embeddedlmg 61586321-3abf-4ec3-ba55b838056f0f48\&FileName=NDR_rapport2011 LR.pdf\&Attachment=False (27.5.2013). (

12. Scottish Diabetes Survey Monitoring Group. Scottish Diabetes Survey 2011. www diabetesinscotland org.uk/Publications/ SDS\%202011.pdf (27.5.2013).

13. Skrivarhaug T, Bangstad HJ, Stene LC et al. Longterm mortality in a nationwide cohort of childhoodonset type 1 diabetic patients in Norway. Diabetologia 2006; 49: 298-305

14. Miller RG, Secrest AM, Sharma RK et al. Improve ments in the life expectancy of type 1 diabetes: the Pittsburgh Epidemiology of Diabetes Complications study cohort. Diabetes 2012: 61: 2987-92.

15. Livingstone SJ, Looker HC, Hothersall EJ et al. Risk of cardiovascular disease and total mortality in adults with type 1 diabetes: Scottish registry linkage study. PLoS Med 2012; 9: e1001321.

16. Writing Team for the Diabetes Control and Complications Trial/Epidemiology of Diabetes Interventions and Complications Research Group. Effect of intensive therapy on the microvascular complications of type 1 diabetes mellitus. JAMA 2002: 287: 2563-9

17. Dahl-Jørgensen K, Brinchmann-Hansen O, Hans sen KF et al. Effect of near normoglycaemia for two years on progression of early diabetic retinopathy, nephropathy, and neuropathy: the Oslo study. Br Med J (Clin Res Ed) 1986; 293: 1195-9.

18. Orchard TJ, Forrest KY, Ellis D et al. Cumulative glycemic exposure and microvascular complications in insulin-dependent diabetes mellitus. The glycemic threshold revisited. Arch Intern Med 1997; 157: 1851-6.

19. Krolewski AS, Kosinski EJ, Warram JH et al. Magnitude and determinants of coronary artery disease in juvenile-onset, insulin-dependent diabetes mellitus. Am J Cardiol 1987; 59: 750-5

20. Laing SP, Swerdlow AJ, Slater SD et al. Mortality from heart disease in a cohort of 23,000 patients with insulin-treated diabetes. Diabetologia 2003; 46: $760-5$

21. Soedamah-Muthu SS, Fuller JH, Mulnier HE et al. High risk of cardiovascular disease in patients with type 1 diabetes in the U.K.: a cohort study using the general practice research database. Diabetes Care 2006; 29: 798-804

22. Kramer CK, Rodrigues TC, Canani LH et al. Diabetic retinopathy predicts all-cause mortality and cardiovascular events in both type 1 and type 2 diabetes. Diabetes Care 2011: 34: 1238-44.

Mottatt 1.2. 2013, første revisjon innsendt 20.3. 2013, godkjent 16.9. 2013. Redaktør Trine B. Haugen. 